University of Nebraska - Lincoln

DigitalCommons@University of Nebraska - Lincoln

\title{
Tillage and Nitrogen Fertilization Influences on Grain and Soil Nitrogen in a Spring Wheat-Fallow System
}

\author{
Ardell Halvorson \\ USDA, Ardell.Halvorson@ars.usda.gov \\ Brian J. Wienhold \\ University of Nebraska-Lincoln, Brian.Wienhold@ars.usda.gov \\ USDA \\ USDA
}

Follow this and additional works at: https://digitalcommons.unl.edu/usdaarsfacpub

Halvorson, Ardell; Wienhold, Brian J.; and USDA, "Tillage and Nitrogen Fertilization Influences on Grain and Soil Nitrogen in a Spring Wheat-Fallow System" (2001). Publications from USDA-ARS / UNL Faculty. 1183.

https://digitalcommons.unl.edu/usdaarsfacpub/1183

This Article is brought to you for free and open access by the U.S. Department of Agriculture: Agricultural Research Service, Lincoln, Nebraska at DigitalCommons@University of Nebraska - Lincoln. It has been accepted for inclusion in Publications from USDA-ARS / UNL Faculty by an authorized administrator of DigitalCommons@University of Nebraska - Lincoln. 


\title{
Tillage and Nitrogen Fertilization Influences on Grain and Soil Nitrogen in a Spring Wheat-Fallow System
}

\author{
Ardell D. Halvorson,* Brian J. Wienhold, and Alfred L. Black
}

\begin{abstract}
Spring wheat (Triticum aestivum L.) is generally produced in the northern Great Plains using tillage and a crop-fallow system. This study evaluated the influence of tillage system [conventional-till (CT), minimum-till (MT), and no-till (NT)] and $N$ fertilizer rate $(0,22$, and $45 \mathrm{~kg} \mathrm{~N} \mathrm{ha}^{-1}$ ) on grain $\mathrm{N}$, grain $\mathrm{N}$ removal from cropping system, and changes in residual postharvest soil $\mathrm{NO}_{3}-\mathrm{N}$ during six rotation cycles of a dryland spring wheat-fallow (SW-F) cropping system. Grain $\mathrm{N}$ concentration increased with increasing $\mathrm{N}$ rate and was higher with CT $\left(33.3 \mathrm{~g} \mathrm{~kg}^{-1}\right)$ than with NT $\left(32.3 \mathrm{~g} \mathrm{~kg}^{-1}\right)$ at $45 \mathrm{~kg} \mathrm{ha}^{-1} \mathrm{~N}$ rate. Grain $N$ removal per crop was greater with $C T\left(70 \mathrm{~kg} \mathrm{~N} \mathrm{ha}^{-1}\right)$ and MT (68 $\left.\mathrm{kg} \mathrm{N} \mathrm{ha}^{-1}\right)$ than with NT $\left(66 \mathrm{~kg} \mathrm{~N} \mathrm{ha}^{-1}\right)$ and tended to increase with increasing $\mathbf{N}$ rate, but varied with rotation cycle. Total grain $\mathbf{N}$ removal in six rotation cycles was in the order: $\mathrm{CT}>\mathrm{MT}>$ NT. Total grain $\mathbf{N}$ removal by six $\mathbf{S W}$ crops was increased by $\mathbf{N}$ fertilization, with only 21 and $17 \%$ of the applied $N$ removed in the grain for the 22 and $45 \mathrm{~kg} \mathrm{ha}^{-1} \mathrm{~N}$ rates, respectively. Postharvest soil $\mathrm{NO}_{3}-\mathrm{N}$ levels in the $150-\mathrm{cm}$ profile varied with $\mathrm{N}$ rate and rotation cycle, with residual $\mathrm{NO}_{3}-\mathrm{N}$ increasing during consecutive dry crop cycles. In contrast, some leaching of $\mathrm{NO}_{3}-\mathrm{N}$ below the $\mathrm{SW}$ root zone may have occurred during wetter crop cycles. Soil profile $\mathrm{NO}_{3}-\mathrm{N}$ levels tended to be greater with CT and MT than with NT. Variation in precipitation during rotation cycles and $\mathbf{N}$ fertilization impacted grain $\mathrm{N}$ removal and residual soil $\mathrm{NO}_{3}-\mathrm{N}$ levels more than tillage system within this SW-F cropping system.
\end{abstract}

$I^{r}$ N the Great Plains, plant-available water and soil erosion are major factors limiting agricultural production (Deibert et al., 1986; Peterson et al., 1996; Stewart, 1990). Farmers need to manage crop residues and tillage to reduce soil erosion and store the limited precipitation for crop production. No-till and MT systems are an effective step in efficiently saving more precipitation for crop production (Aase and Schaefer, 1996; Black and Bauer, 1990; Peterson et al., 1996; Tanaka and Anderson, 1997).

The traditional CT, crop-fallow system of farming with a 20- to 21-mo fallow period often fails to use water efficiently. Minimum-till and NT systems used with

A.D. Halvorson, USDA-ARS, P.O. Box E, Fort Collins, CO 80522; B.J. Wienhold, USDA-ARS, 119 Keim Hall, East Campus, Univ. Nebraska, Lincoln, NE 68583; and Alfred L. Black, USDA-ARS, retired, 226 E. Circle Dr., Canon City, CO 81212. Contribution from USDA-ARS. The U.S. Department of Agriculture offers its programs to all eligible persons regardless of race, color, age, sex, or national origin, and is an equal opportunity employer. Received 26 Jan. 2001.

*Corresponding author (adhalvor@lamar.colostate.ed).

Published in Agron. J. 93:1130-1135 (2001). crop-fallow have the potential to increase water movement through the soil profile, leading to development of dryland saline-seeps (Halvorson and Black, 1974, Halvorson, 1990). The work of Tanaka $(1985,1989)$ showed more soil water storage and surface residue cover with chemical fallow than with stubble mulch fallow in northeast Montana.

Increased water storage with MT and NT may result in increased movement of $\mathrm{NO}_{3}-\mathrm{N}$ through and below the root zone of SW in a SW-F system. Movement of $\mathrm{NO}_{3}-\mathrm{N}$ below the root zone of crops has potential to increase the $\mathrm{NO}_{3}-\mathrm{N}$ content of ground water used for human consumption. Soil $\mathrm{NO}_{3}-\mathrm{N}$ movement below the root zone under crop-fallow conditions has been reported in the northern Great Plains (Campbell et al., 1993; Halvorson and Black, 1985; Izaurralde et al., 1995; Grant and Lafond, 1994).

Tillage and $\mathrm{N}$ fertilization practices may influence the quantity of postharvest residual soil $\mathrm{N}$ remaining in the root zone. Adequate soil fertility has been shown to increase water-use efficiency by increasing crop yields (Black et al., 1981), thus reducing the $\mathrm{NO}_{3}-\mathrm{N}$ leaching potential. A 12-yr study evaluating the influence of tillage system and $\mathrm{N}$ fertility rate on SW yields in a SW-F system was recently completed (Halvorson et al., 2000). This paper reports the effects of tillage and $\mathrm{N}$ fertilization rate on grain $\mathrm{N}$, quantity of $\mathrm{N}$ removed in the grain during six rotation cycles of a SW-F cropping system, and residual fall soil $\mathrm{NO}_{3}-\mathrm{N}$ following SW harvest.

\section{MATERIALS AND METHODS}

The study was initiated in 1984 on a Temvik-Wilton silt loam soil (fine-silty, mixed Typic and Pachic Haploborolls) located near Mandan, ND. Surface soil $\mathrm{pH}$ was 6.4, soil organic $\mathrm{C}$ was $21.4 \mathrm{~g} \mathrm{~kg}^{-1}$, and $\mathrm{NaHCO}_{3}$-extractable soil test $\mathrm{P}$ was 20 to $26 \mathrm{mg} \mathrm{kg}^{-1}$ in the spring of 1984 (Black and Tanaka, 1997). Hard-red SW was produced in a crop-fallow system under three tillage systems, CT, MT, and NT. Nitrogen fertilizer was applied in early spring each crop year as a broadcast application of $\mathrm{NH}_{4} \mathrm{NO}_{3}$ at rates of 0,22 , and $45 \mathrm{~kg} \mathrm{~N} \mathrm{ha}^{-1}$, except for 1991 and 1992 (Rotation Cycle 4), when no $\mathrm{N}$ was applied because of a buildup of residual soil $\mathrm{NO}_{3}-\mathrm{N}$ due to drought conditions and low yields in 1988 and 1989. Each main block of the study was 137.2 by $73.1 \mathrm{~m}$ in size. Tillage plots $(45.7$ by $73.1 \mathrm{~m}$ ) were oriented in a north-south direction,

Abbreviations: CT, conventional-till; F, fallow; MT, minimum-till; NT, no-till; SW, spring wheat. 
$\mathrm{N}$ plots (137.2 by $24.4 \mathrm{~m}$ ) in an east-west direction across all tillage plots with each individual tillage by $\mathrm{N}$ plot being 45.7 by $24.4 \mathrm{~m}$. Experimental design was a strip-split plot with tillage and $\mathrm{N}$ rate treatments stripped with three replications. Duplicate sets of plots (SW-F and F-SW cropping sequences) were established in 1984 to allow all phases of the crop-fallow system to be present each year from 1985 through 1996. Data presented here represent an average from the duplicate set of plots to get an overall long-term representation of the SW-F system. Six rotation cycles of the SW-F system were completed in the $12 \mathrm{yr}(1985-1996)$ of this study (Table 1). The total quantity of $\mathrm{N}$ applied during the $12 \mathrm{yr}$ was 0,112 , and $224 \mathrm{~kg}$ $\mathrm{N} \mathrm{ha}^{-1}$ for the 0,22 , and $45 \mathrm{~kg} \mathrm{~N} \mathrm{ha}^{-1}$ treatments, respectively.

The fallow period began in September each year following SW harvest in August and continued for about 20 mo until SW planting in May. Precipitation for the fallow period and crop period, and total for each rotation cycle (average for duplicate sets of plots) are reported in Table 1. Agronomic practices used for each tillage treatment were previously described by Halvorson et al. (2000).

Grain samples collected at harvest each year were analyzed for $\mathrm{N}$ content using a wet acid digest procedure (Lachat Instruments, 1992). The samples were ground to pass a $0.85-\mathrm{mm}$ screen prior to analysis. In 1994 and 1996, grain N was determined with a Carlo-Erba C-N analyzer (Schepers et al., 1989). ${ }^{1}$ The grain $\mathrm{N}$ concentration and total amount of $\mathrm{N}$ removed each year in the grain was determined.

Soil samples, one 3-cm-diam. core per plot, were collected from each tillage and $\mathrm{N}$ fertilizer treatment each fall after SW harvest from the fallow and crop phases of the rotation cycle for $\mathrm{NO}_{3}-\mathrm{N}$ analyses. Samples were collected in 30-cm increments to a depth of $150 \mathrm{~cm}$. Soil $\mathrm{NO}_{3}-\mathrm{N}$ was determined by autoanalyzer (Lachat Instruments, 1989; Technicon Industrial Systems, 1973) on a 5:1 extract/soil ratio using $2 \mathrm{M} \mathrm{KCl} \mathrm{ex-}$ tracting solution from 1985 to 1993 and a $0.01 \mathrm{M} \mathrm{CaSO}_{4}$ extracting solution from 1993 through 1996. Laboratory check soils were run to assure that the $\mathrm{NO}_{3}-\mathrm{N}$ analyses were similar for both extraction methods and instruments used in this study.

Precipitation was measured from April through October each year with a recording rain-gauge at the field site. November through March precipitation was estimated from the U.S. Weather Bureau measurements made at the Northern Great Plains Research Laboratory at Mandan, ND located approximately $5 \mathrm{~km}$ northeast of the site.

Analysis of variance procedures were conducted using SAS statistical procedures (SAS Institute Inc., 1991). All differences discussed are significant at the 0.05 probability level unless otherwise stated. An LSD was calculated only when the analysis of variance $F$-test was significant at the 0.05 probability level unless otherwise indicated.

\section{RESULTS AND DISCUSSION}

\section{Grain Yields}

There was substantial variation in precipitation received during the six rotation cycles of this study. For the rotation cycles of this SW-F system, precipitation during the fallow $(328 \mathrm{~mm})$ and crop $(156 \mathrm{~mm})$ periods were lowest for Rotation Cycle 3 with a total average precipitation amount of $484 \mathrm{~mm}$ (Table 1). Rotation

\footnotetext{
${ }^{1}$ Trade names and company names are included for the benefit of the reader and do not imply any endorsement or preferential treatment of the product by the USDA-ARS.
}

Table 1. Average precipitation received during fallow $(20 \mathrm{mo})$ and crop (4 mo) periods for each rotation cycle at the research site southwest of Mandan, ND, from 1983 through 1996.

\begin{tabular}{lcccc}
\hline $\begin{array}{l}\text { Rotation } \\
\text { cycle }\end{array}$ & $\begin{array}{l}\text { Crop years } \\
\text { in rotation }\end{array}$ & Fallow & Crop & $\begin{array}{c}\text { Rotation } \\
\text { total }\end{array}$ \\
\hline & & & mm & \\
\cline { 3 - 5 } 1 & $1985-1986$ & 531 & 328 & $\mathbf{8 5 9}$ \\
2 & $1987-1988$ & $\mathbf{6 6 2}$ & $\mathbf{2 2 0}$ & $\mathbf{8 8 2}$ \\
3 & $1989-1990$ & $\mathbf{3 2 8}$ & 156 & 484 \\
4 & $1991-1992$ & 403 & 236 & $\mathbf{6 3 9}$ \\
5 & $1993-1994$ & 645 & 357 & $\mathbf{1 0 0 2}$ \\
6 & $1995-1996$ & 794 & 328 & 1122 \\
Average & & 561 & 271 & $\mathbf{8 3 1}$ \\
\hline
\end{tabular}

Cycles 5 and 6 were the wettest with 1002 and $1122 \mathrm{~mm}$ total precipitation for the rotation cycles, respectively.

Annual grain yields were the subject of a previous paper (Halvorson et al., 2000) and will not be discussed in detail here. Average grain yields for each rotation cycle are presented briefly to assist the reader in understanding the relationship of grain yields to grain $\mathrm{N}$ removal as affected by tillage and $\mathrm{N}$ treatments. Grain yields decreased as tillage intensity decreased [CT (2267 $\left.\mathrm{kg} \mathrm{ha}^{-1}\right)>$ MT $\left(2167 \mathrm{~kg} \mathrm{ha}^{-1}\right)>$ NT $\left.\left(2101 \mathrm{~kg} \mathrm{ha}^{-1}\right)\right]$.

Grain yields were affected differently by $\mathrm{N}$ fertilization during the earlier rotation cycles when growing season conditions were drier than during the later rotation cycles that were wetter (Table 2). For Rotation Cycles 1 to $3, \mathrm{~N}$ fertilization had no effect on grain yields. In Rotation Cycle 4, grain yields were depressed at the $22 \mathrm{~kg} \mathrm{ha}^{-1} \mathrm{~N}$ rate. During Rotation Cycles 5 and 6, grain yields were generally increased by $\mathrm{N}$ fertilization, which probably should be expected due to the high level of precipitation during the crop period (Table 1).

\section{Grain Nitrogen}

Grain $\mathrm{N}$ concentration, averaged over rotation cycles, was influenced by a significant tillage $\times \mathrm{N}$ interaction. Grain $\mathrm{N}$ concentration increased with increasing $\mathrm{N}$ rate for each of the tillage treatments (Fig. 1). Grain N concentrations were similar for all tillage treatments with no $\mathrm{N}$ applied. At the $22 \mathrm{~kg} \mathrm{ha}^{-1} \mathrm{~N}$ rate, grain $\mathrm{N}$ concentrations were greater with CT and MT than with NT. At the $45 \mathrm{~kg} \mathrm{ha}^{-1} \mathrm{~N}$ rate, grain $\mathrm{N}$ concentrations were higher with CT than with NT. Grain N concentration varied with rotation cycle with $\mathrm{N}$ concentrations of 32 , $33,38,34,25$, and $29 \mathrm{~g} \mathrm{~kg}^{-1}$ for Rotation Cycles 1, 2, $3,4,5$, and 6, respectively $\left(\mathrm{LSD}_{0.05}=1 \mathrm{~g} \mathrm{~kg}^{-1}\right)$. Grain

Table 2. Grain yields of six spring wheat crops over $12 \mathrm{yr}$ in a spring wheat-fallow cropping system as a function of $\mathbf{N}$ rate, averaged across tillage system, at Mandan, ND. $\dagger$

\begin{tabular}{|c|c|c|c|c|c|c|c|}
\hline \multirow[b]{2}{*}{ N Rate } & \multicolumn{6}{|c|}{ Rotation cycle } & \multirow[b]{2}{*}{ Mean } \\
\hline & 1 & 2 & 3 & 4 & 5 & 6 & \\
\hline $\mathbf{k g ~ h a}^{-1}$ & & & & kg ha ${ }^{-}$ & & & \\
\hline $\mathbf{0}$ & $2600 \div$ & 1514 & 2173 & 2832 & 1695 & 1847 & 2110 \\
\hline 22 & 2625 & 1471 & 2098 & 2673 & 2085 & 2084 & 2173 \\
\hline 45 & 2568 & 1507 & 2166 & 2741 & 2238 & 2050 & 2212 \\
\hline
\end{tabular}

$\dagger$ Significant $\mathbf{N}$ rate $\times$ rotation cycle interaction.

$+\mathbf{L S D}_{0.05}=148 \mathrm{~kg} \mathrm{ha}^{-1}$ for comparing $\mathbf{N}$ rates within rotation cycle; $\mathbf{L S D}_{0.05}=198 \mathrm{~kg} \mathrm{ha}^{-1}$ for comparing rotation cycles within $\mathrm{N}$ rates; $\mathrm{LSD}_{0.05}=50 \mathrm{~kg} \mathrm{ha}^{-1}$ for comparing means. 


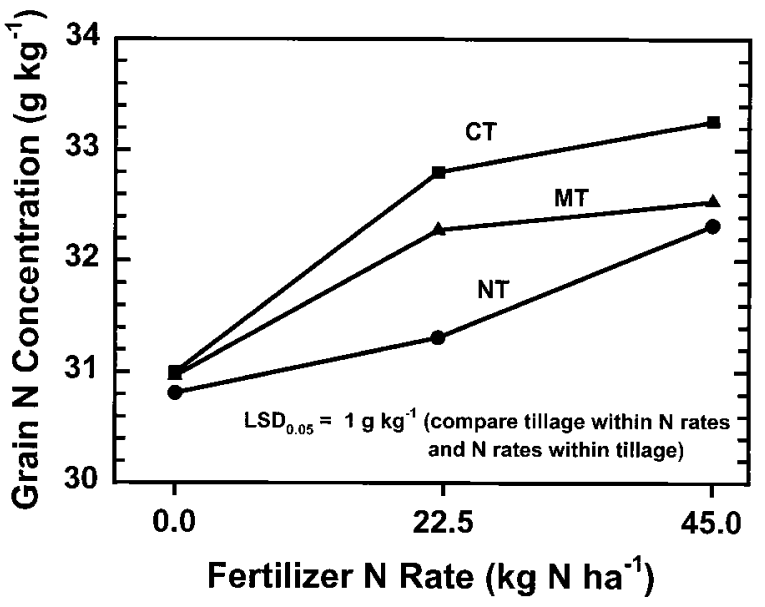

Fig. 1. Grain $\mathbf{N}$ concentration as a function of $\mathbf{N}$ rate for the conventional-till (CT), minimum-till (MT), and no-till (NT) treatments.

$\mathrm{N}$ concentrations were higher during the earlier drier rotation cycles (1-3) than the wetter later Rotation $\mathrm{Cy}$ cles 5 and 6 .

Grain $\mathrm{N}$ removal per crop, averaged over $\mathrm{N}$ rates and rotation cycles, was affected by tillage treatment, with a greater grain $\mathrm{N}$ removal $\left(70 \mathrm{~kg} \mathrm{~N} \mathrm{ha}^{-1}\right)$ with $\mathrm{CT}$ than with NT (66 kg N ha-1). Grain $\mathrm{N}$ removal was greater with MT $\left(68 \mathrm{~kg} \mathrm{~N} \mathrm{ha}^{-1}\right)$ than with NT.

Grain $\mathrm{N}$ removal per crop varied with $\mathrm{N}$ rate and rotation cycle. Grain $\mathrm{N}$ removal was generally increased by $\mathrm{N}$ fertilization and increasing $\mathrm{N}$ rate during each of the rotation cycles, except for Rotation Cycles 4 and 6 (Table 3 ). For the six rotation cycles, grain $\mathrm{N}$ removal for the $22 \mathrm{~kg} \mathrm{ha}^{-1} \mathrm{~N}$ rate was significantly greater than with the zero $\mathrm{N}$ rate for Rotation Cycles 1, 5, and 6, or $50 \%$ of the time. Applying $45 \mathrm{~kg} \mathrm{~N} \mathrm{ha}^{-1}$ increased grain $\mathrm{N}$ removal above that of the zero $\mathrm{N}$ rate during Rotation Cycles 1, 2, 3, and 5, or $67 \%$ of the time. Differences in grain $\mathrm{N}$ removal were observed between the 22 and $45 \mathrm{~kg} \mathrm{ha}^{-1} \mathrm{~N}$ rates for Rotation Cycles 2, 3, 4, 5, and 6 . In Rotation Cycle 4, an unexplainable decrease in grain $\mathrm{N}$ removal was observed with application of $22 \mathrm{~kg} \mathrm{~N}$ $\mathrm{ha}^{-1}$. In Rotation Cycle 6, the application of $45 \mathrm{~kg} \mathrm{~N} \mathrm{ha}^{-1}$ resulted in an unexplained decrease in grain $\mathrm{N}$ removal. Grain N removal was lowest during Rotation Cycle 2 when grain yields were depressed due to drought. The overall trend for all rotation cycles was for grain $\mathrm{N}$ removal to increase with increasing $\mathrm{N}$ rate (Table 3 ).

Table 3. Grain $\mathbf{N}$ removal with six spring wheat crops over 12 yr in a spring wheat-fallow cropping system as a function of $\mathbf{N}$ rate, averaged across tillage system, at Mandan, ND. $\dagger$

\begin{tabular}{|c|c|c|c|c|c|c|c|c|}
\hline \multirow[b]{2}{*}{ N Rate } & \multicolumn{6}{|c|}{ Rotation cycle } & \multirow[b]{2}{*}{ Mean } & \multirow[b]{2}{*}{ Total } \\
\hline & 1 & 2 & 3 & 4 & 5 & 6 & & \\
\hline $\mathrm{kg} \mathrm{ha}^{-1}$ & & & & $\mathbf{N}$ & 1 & & & \\
\hline $\mathbf{0}$ & $79 \%$ & 45 & 81 & 90 & 40 & 58 & 66 & 388 \\
\hline 22 & 83 & 46 & 82 & 87 & 53 & 60 & 69 & 411 \\
\hline 45 & 83 & 48 & 85 & 91 & 58 & 54 & 70 & 425 \\
\hline
\end{tabular}

$\dagger$ Significant $\mathbf{N}$ rate $\times$ rotation cycle interaction.

$\neq \mathbf{L S D}_{0.05}=2 \mathrm{~kg} \mathrm{~N} \mathrm{ha}^{-1}$ for comparing $\mathbf{N}$ rates within rotation cycle; $\mathbf{L S D}_{0.05}=\mathbf{2} \mathrm{kg} \mathrm{N} \mathrm{ha}^{-1}$ for comparing rotation cycles within $\mathbf{N}$ rates; $\mathbf{L S D}_{0.05}=2 \mathrm{~kg} \mathrm{~N} \mathrm{ha}^{-1}$ for comparing means; $\mathbf{L S D}_{0.05}=14 \mathrm{~kg} \mathrm{ha}^{-1}$ for comparing total grain $\mathrm{N}$ removal.
Table 4. Total fall $\mathrm{NO}_{3}-\mathrm{N}$ level in soil profile ( $(0-$ to $150-\mathrm{cm}$ depth) in fallow (Sept.-Oct.) prior to spring wheat planting (May) for each rotation cycle as a function of $\mathbf{N}$ rate, averaged across tillage system, in a SP cropping system at Mandan, ND. $\dagger$

\begin{tabular}{|c|c|c|c|c|c|c|c|}
\hline \multirow[b]{2}{*}{ N Rate } & \multicolumn{6}{|c|}{ Rotation cycle } & \multirow[b]{2}{*}{ Mean } \\
\hline & 1 & 2 & 3 & 4 & 5 & 6 & \\
\hline $\mathbf{k g ~ h a}^{-1}$ & & & -1 & $\mathbf{O}_{3}-1$ & 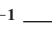 & & \\
\hline 0 & $136 \%$ & 75 & 144 & 169 & 70 & 77 & 112 \\
\hline 22 & 144 & 77 & 177 & 218 & 134 & 76 & 138 \\
\hline 45 & 125 & 80 & 157 & 241 & 117 & 86 & 136 \\
\hline
\end{tabular}

$\dagger$ Significant $\mathbf{N}$ rate $\times$ rotation cycle interaction.

$\$ \mathbf{L S D}_{0.05}=33 \mathrm{~kg} \mathrm{NO}_{3}-\mathrm{N} \mathrm{ha}^{-1}$ (compare $\mathbf{N}$ rate within rotation cycle); $\mathbf{L S D}_{0.05}=37 \mathrm{~kg} \mathrm{NO}_{3}-\mathrm{N} \mathrm{ha}^{-1}$ (compare rotation cycle within $\mathbf{N}$ rates); LSD $_{0.05}=$ n.s. and $\mathbf{L S D}_{0.10}=19 \mathrm{~kg} \mathrm{NO}_{3}-\mathrm{N} \mathrm{ha}^{-1}$ (compare means).

Total grain $\mathrm{N}$ removal in six crops decreased with decreasing tillage intensity [CT $\left(422 \mathrm{~kg} \mathrm{~N}^{-1}\right)>$ MT $\left.\left(409 \mathrm{~kg} \mathrm{~N} \mathrm{ha}^{-1}\right)>\mathrm{NT}\left(393 \mathrm{~kg} \mathrm{~N} \mathrm{ha}^{-1}\right)\right]$, which reflects the trends in grain yields and grain $\mathrm{N}$ concentrations for the tillage treatments.

The total quantity of $\mathrm{N}$ removed in the grain of six crops averaged $388 \mathrm{~kg} \mathrm{~N}^{-1}$ with no $\mathrm{N}$ applied. Only $23 \mathrm{~kg} \mathrm{ha}^{-1}$ more $\mathrm{N}$ was removed in the grain with the application of $22 \mathrm{~kg} \mathrm{~N}^{-1}$ compared with the zero $\mathrm{N}$ rate with a $\mathrm{N}$ use efficiency of $21 \%$ of the $112 \mathrm{~kg} \mathrm{ha}^{-1}$ fertilizer $\mathrm{N}$ applied. Only $37 \mathrm{~kg} \mathrm{ha}^{-1}$ more $\mathrm{N}$ was removed in the grain with the application of $45 \mathrm{~kg} \mathrm{~N}^{-1}$ compared with no $\mathrm{N}$ applied with a $\mathrm{N}$ use efficiency of $17 \%$ of the $224 \mathrm{~kg} \mathrm{ha}^{-1}$ fertilizer $\mathrm{N}$ applied. Thus, more $\mathrm{N}$ was being applied to the SW-F system at the two highest $\mathrm{N}$ rates than was being removed in the grain.

\section{Soil Nitrate-Nitrogen Accumulation and Distribution}

Fall (September-October) $\mathrm{NO}_{3}-\mathrm{N}$ levels in the 0- to $150-\mathrm{cm}$ soil depth in fallow (at the end of the second summer) varied with $\mathrm{N}$ rate and rotation cycle (Table 4). Fall soil $\mathrm{NO}_{3}-\mathrm{N}$ levels were similar for all $\mathrm{N}$ rates during Rotation Cycles 1 and 2. Fall soil $\mathrm{NO}_{3}-\mathrm{N}$ levels in fallow increased with $\mathrm{N}$ fertilization rate during Rotation Cycles 3, 4, and 5; however, $\mathrm{N}$ fertilization had no effect on soil $\mathrm{NO}_{3}-\mathrm{N}$ in Rotation Cycle 6. When averaged over all rotation cycles, $\mathrm{N}$ fertilization increased the level of fall soil $\mathrm{NO}_{3}-\mathrm{N}$ in fallow (Table 4). Soil $\mathrm{NO}_{3}-\mathrm{N}$ levels increased following the low crop yields of Rotation Cycle 2 due to low precipitation during the crop phase of the rotation. Soil $\mathrm{NO}_{3}-\mathrm{N}$ levels in fallow were highest for Rotation Cycles 3 and 4, then decreased during Rotation Cycle 6.

Fall soil $\mathrm{NO}_{3}-\mathrm{N}$ levels in the fallow phase of the $\mathrm{SW}-\mathrm{F}$ rotation varied with tillage treatment, rotation cycle, and soil depth (Table 5). Soil $\mathrm{NO}_{3}-\mathrm{N}$ levels tended to be higher in the upper soil depths than lower soil depths of the $150-\mathrm{cm}$ profile for all tillage treatments during Rotation Cycles 1, 2, and 3. The $\mathrm{NO}_{3}-\mathrm{N}$ levels increased in the lower soil depths during Rotation Cycles 4 and 5. Soil $\mathrm{NO}_{3}-\mathrm{N}$ levels in the lower soil depths were lower for Rotation Cycle 6 than for Rotation Cycle 5, which may be an indication that some $\mathrm{NO}_{3}-\mathrm{N}$ may have been lost below the root zone of SW during the wetter environments of Rotation Cycles 5 and 6. Variations in soil 
Table 5. Fall soil $\mathrm{NO}_{3}-\mathrm{N}$ level in fallow (Sept.-Oct.) prior to $\mathrm{SW}$ planting (May) with depth for each rotation cycle as a function of tillage system, averaged across $\mathrm{N}$ rates, in a SW-F cropping system at Mandan, ND. $\dagger$

\begin{tabular}{|c|c|c|c|c|c|c|c|c|}
\hline \multirow[b]{2}{*}{ Tillage } & \multirow[b]{2}{*}{ Soil depth } & \multicolumn{6}{|c|}{ Rotation cycle } & \multirow[b]{2}{*}{ Mean } \\
\hline & & 1 & 2 & 3 & 4 & 5 & 6 & \\
\hline & cm & & & $-\mathrm{kg}$ & $\mathbf{O}_{3}-\Gamma$ & $\mathbf{a}^{-1}$ & & \\
\hline \multirow[t]{6}{*}{ CT } & 0-30 & $74 \%$ & 33 & 85 & 53 & 30 & 36 & 52 \\
\hline & $30-60$ & 21 & 16 & 41 & 49 & 10 & 18 & 26 \\
\hline & $60-90$ & 12 & 13 & 21 & 56 & 12 & 14 & 21 \\
\hline & 90-120 & 16 & 10 & 14 & 27 & 28 & 9 & 17 \\
\hline & $120-150$ & 17 & 15 & 16 & 21 & 31 & 8 & 18 \\
\hline & §Total & 140 & 87 & 176 & 207 & 110 & 84 & 134 \\
\hline \multirow[t]{6}{*}{ MT } & 0-30 & 67 & 27 & 60 & 64 & 30 & 31 & 46 \\
\hline & $30-60$ & 29 & 16 & 41 & 49 & 11 & 17 & 27 \\
\hline & $60-90$ & 12 & 13 & 20 & 63 & 32 & 13 & 26 \\
\hline & 90-120 & 13 & 10 & 11 & 28 & 10 & 10 & 14 \\
\hline & 120-150 & 14 & 9 & 10 & 14 & 25 & 8 & 13 \\
\hline & Total & 135 & 76 & 142 & 218 & 108 & 79 & 126 \\
\hline \multirow[t]{6}{*}{ NT } & 0-30 & 26 & 23 & 72 & 57 & 30 & 24 & 39 \\
\hline & $30-60$ & 58 & 15 & 39 & 39 & 12 & 16 & 30 \\
\hline & $60-90$ & 18 & 14 & 24 & 53 & 32 & 15 & 26 \\
\hline & $90-120$ & 15 & 10 & 14 & 38 & 12 & 11 & 17 \\
\hline & $120-150$ & 12 & 9 & 11 & 16 & 18 & 9 & 13 \\
\hline & Total & 129 & 71 & 160 & 204 & 103 & 76 & 125 \\
\hline
\end{tabular}

$\dagger$ Significant tillage $\times$ rotation cycle $\times$ soil depth interaction.

$\ddagger$ LSD $_{0.05}=17 \mathrm{~kg} \mathrm{NO}_{3}-\mathrm{N} \mathrm{ha}^{-1}$ (compare tillage within rotation cycle $\times$ soil depth); $\mathbf{L S D}_{0.05}=17 \mathrm{~kg} \mathrm{NO}_{3}-\mathrm{N} \mathrm{ha}^{-1}$ (compare rotation cycle within tillage $\times$ soil depth); $\mathbf{L S D}_{0.05}=17 \mathrm{~kg} \mathrm{NO}_{3}-\mathrm{N} \mathrm{ha}^{-1}$ (compare soil depth within tillage $\times$ rotation cycle).

$\S$ Tillage $\times$ rotation cycle interaction was not significant for total $\mathrm{NO}_{3}-\mathrm{N}$ in soil profile.

$\mathrm{NO}_{3}-\mathrm{N}$ within a given soil depth among tillage treatments may have resulted in this significant interaction. Differences between tillage treatments are not obvious.

Total fall $\mathrm{NO}_{3}-\mathrm{N}$ in the $150-\mathrm{cm}$ soil profile following $\mathrm{SW}$ harvest varied with $\mathrm{N}$ rate and rotation cycle (Table 6). Nitrogen rate had no effect on residual soil $\mathrm{NO}_{3}-\mathrm{N}$ in Rotation Cycle 1, but increased residual soil $\mathrm{NO}_{3}-\mathrm{N}$ in Rotation Cycles 2 through 4. Overall, the trend was for $\mathrm{N}$ rate to increase the level of residual $\mathrm{NO}_{3}-\mathrm{N}$ in the soil profile. During Rotation Cycles 2 through 4 when precipitation was low during the crop phase, residual soil $\mathrm{NO}_{3}-\mathrm{N}$ increased in the $150-\mathrm{cm}$ soil profile. Residual $\mathrm{NO}_{3}-\mathrm{N}$ levels were much lower for Rotation Cycles 5 and 6, which had above average precipitation during the fallow and crop phases of the SW-F rotation. Good yields and high grain N removal during Rotation Cycle 4, without further $\mathrm{N}$ fertilizer application, probably contributed to the lower postharvest $\mathrm{NO}_{3}-\mathrm{N}$ levels in Rotation Cycle 5 for the previously fertilized treatments. Leaching of $\mathrm{NO}_{3}-\mathrm{N}$ below the root zone of the SW during the wet Rotation Cycles 5 and 6 could have also contributed to the lower postharvest $\mathrm{NO}_{3}-\mathrm{N}$ levels since more soil $\mathrm{NO}_{3}-\mathrm{N}$ was present at the end of the crop phase of Rotation Cycle 4 and fallow phase of Rotation Cycle 5 than was removed by the SW crop. Total postharvest soil $\mathrm{NO}_{3}-\mathrm{N}$ levels were not significantly affected by tillage treatment with average postharvest $\mathrm{NO}_{3}-\mathrm{N}$ levels of 81,81 , and $74 \mathrm{~kg} \mathrm{~N} \mathrm{ha}^{-1}$ in the 0 - to $150-\mathrm{cm}$ soil profile for the CT, MT, and NT treatments, respectively.

A tillage $\times N$ rate $\times$ rotation cycle $\times$ soil depth interaction (Table 7) shows that $\mathrm{NO}_{3}-\mathrm{N}$ levels throughout the soil profile were relatively low for all tillage and
Table 6. Total fall $\mathrm{NO}_{3}-\mathrm{N}$ level in soil profile ( $(0-$ to $150-\mathrm{cm}$ depth) after spring wheat harvest for each rotation cycle as a function of $\mathbf{N}$ rate, averaged across tillage systems, in a spring wheatfallow cropping system in Mandan, ND. $\dagger$

\begin{tabular}{|c|c|c|c|c|c|c|c|}
\hline \multirow[b]{2}{*}{ N Rate } & \multicolumn{6}{|c|}{ Rotation cycle } & \multirow[b]{2}{*}{ Mean } \\
\hline & 1 & 2 & 3 & 4 & 5 & 6 & \\
\hline $\mathbf{k g ~ h a}^{-1}$ & & & $-\mathbf{k}$ & $\mathrm{O}_{3}-\mathbf{N}$ & 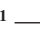 & & \\
\hline 0 & 38 & 72 & 111 & 59 & 13 & 36 & 55 \\
\hline 22 & 40 & 108 & 154 & 122 & 27 & 44 & 82 \\
\hline 45 & 49 & 113 & 197 & 166 & 30 & 41 & 99 \\
\hline
\end{tabular}

+ Significant $\mathbf{N}$ rate $\times$ rotation cycle interaction.

$+\mathrm{LSD}_{0.05}=28 \mathrm{~kg} \mathrm{NO}_{3}-\mathbf{N} \mathrm{ha}^{-1}$ (compare $\mathrm{N}$ rate within rotation cycle); $\mathrm{LSD}_{0.05}=29 \mathrm{~kg} \mathrm{NO}_{3}-\mathrm{N} \mathrm{ha}^{-1}$ (compare rotation cycle within $\mathrm{N}$ rates); $\mathbf{L S D}_{0.05}=21 \mathrm{~kg} \mathrm{NO}-\mathrm{N} \mathrm{ha}^{-1}$ (compare means).

$\mathrm{N}$ treatments following SW harvest for Rotation Cycle 1. During the drier Rotation Cycles 2 and 3, postharvest $\mathrm{NO}_{3}-\mathrm{N}$ levels within the soil profile increased at all depths in the profile with $\mathrm{N}$ fertilization increasing the level of $\mathrm{NO}_{3}-\mathrm{N}$. Residual $\mathrm{NO}_{3}-\mathrm{N}$ levels were still fairly high for all tillage treatments and increased with $\mathrm{N}$ rate following SW harvest in Rotation Cycle 4, which was not fertilized, had high yields, and a high level of grain $\mathrm{N}$ removal. The very low levels of postharvest $\mathrm{NO}_{3}-\mathrm{N}$ observed throughout the soil profile for all tillage and $\mathrm{N}$ rates for Rotation Cycle 5 would indicate that some $\mathrm{NO}_{3}-\mathrm{N}$ was potentially lost from the root zone due to leaching. This is supported by the high level of fall soil $\mathrm{NO}_{3}-\mathrm{N}$ found in the soil profile of the fallow phase of Rotation Cycle 5, the fall prior to planting of the SW crop for Rotation Cycle 5 (Table 4). The quantity of $\mathrm{N}$ in the $150-\mathrm{cm}$ soil profile was twice that removed in the grain (Table 3) during Rotation Cycle 5. Thus, crop N uptake and grain $\mathrm{N}$ removal would not account for the low level of postharvest $\mathrm{NO}_{3}-\mathrm{N}$ in the soil profile for Rotation Cycle 5. Postharvest soil $\mathrm{NO}_{3}-\mathrm{N}$ levels remained low in the profile for Rotation Cycle 6 for all tillage and $\mathrm{N}$ rate treatments.

Although the effects of tillage treatment on postharvest soil $\mathrm{NO}_{3}-\mathrm{N}$ is not very obvious, the general trend appears to be for postharvest soil $\mathrm{NO}_{3}-\mathrm{N}$ levels to be lower with NT than with CT and MT treatments (Table 7 ). This would be consistent with the soil $\mathrm{NO}_{3}-\mathrm{N}$ observations made among tillage treatments in the adjacent annual cropping rotation (Halvorson et al., 2001). Differences in soil $\mathrm{NO}_{3}-\mathrm{N}$ among tillage treatments in the SW-F system were not as obvious as in the annual crop (SW-winter wheat-sunflower) rotation. Although grain $\mathrm{N}$ removal was greater with $\mathrm{CT}$ than with $\mathrm{NT}$, soil $\mathrm{NO}_{3}-\mathrm{N}$ in the profile tended to be greater with $\mathrm{CT}$ than with NT. The higher soil $\mathrm{NO}_{3}-\mathrm{N}$ levels for CT probably reflects the effects of tillage on decomposing crop residues and increased $\mathrm{N}$ mineralization compared with the NT system where residue decomposition is slower (Wienhold and Halvorson, 1999). Wienhold and Halvorson (1998) reported that the NT system had a slightly higher level of total soil $\mathrm{N}$ than the CT system in the surface soil. Thus under NT, more of the N appears to be tied up in soil organic matter and crop residues than in the CT system, resulting in lower soil profile $\mathrm{NO}_{3}-\mathrm{N}$ levels with NT than with CT. 
Table 7. Soil $\mathrm{NO}_{3}-\mathrm{N}$ after spring wheat harvest with depth for each rotation cycle as a function of tillage and $N$ treatments in a spring wheat-fallow cropping system at Mandan, ND. $\dagger$

\begin{tabular}{|c|c|c|c|c|c|c|c|c|}
\hline \multirow[b]{2}{*}{ Tillage } & \multirow[b]{2}{*}{ N Rate } & \multirow[b]{2}{*}{ Soil depth } & \multicolumn{6}{|c|}{ Rotation cycle } \\
\hline & & & 1 & 2 & 3 & 4 & 5 & 6 \\
\hline & $\mathrm{kg} \mathrm{ha}^{-1}$ & cm & — & -1 & $\mathrm{NO}_{3-}$ & $\mathbf{h a}^{-}$ & & \\
\hline CT & 0 & $\begin{array}{l}0-30 \\
30-60 \\
60-90 \\
90-120 \\
120-150\end{array}$ & $\begin{array}{r}8 \\
8 \\
11 \\
5 \\
7\end{array}$ & $\begin{array}{l}30 \\
14 \\
14 \\
11 \\
12\end{array}$ & $\begin{array}{r}56 \\
35 \\
13 \\
9 \\
9 \\
13\end{array}$ & $\begin{array}{r}16 \\
6 \\
5 \\
8 \\
8 \\
12\end{array}$ & $\begin{array}{l}7 \\
1 \\
1 \\
1 \\
4\end{array}$ & $\begin{array}{r}16 \\
4 \\
3 \\
5 \\
9\end{array}$ \\
\hline MT & 0 & $\begin{array}{l}0-30 \\
30-60 \\
60-90 \\
90-120 \\
120-150\end{array}$ & $\begin{array}{l}9 \\
8 \\
7 \\
5 \\
5\end{array}$ & $\begin{array}{r}33 \\
9 \\
9 \\
8 \\
8 \\
11\end{array}$ & $\begin{array}{r}46 \\
30 \\
22 \\
8 \\
8 \\
10\end{array}$ & $\begin{array}{r}13 \\
9 \\
20 \\
9 \\
15\end{array}$ & $\begin{array}{l}6 \\
2 \\
7 \\
2 \\
6\end{array}$ & $\begin{array}{r}14 \\
4 \\
3 \\
4 \\
9\end{array}$ \\
\hline NT & $\mathbf{0}$ & $\begin{array}{l}0-30 \\
30-60 \\
60-90 \\
90-120 \\
120-150\end{array}$ & $\begin{array}{l}9 \\
8 \\
8 \\
9 \\
9\end{array}$ & $\begin{array}{r}27 \\
10 \\
12 \\
8 \\
8\end{array}$ & $\begin{array}{r}43 \\
19 \\
12 \\
7 \\
7\end{array}$ & $\begin{array}{r}15 \\
9 \\
12 \\
11 \\
16\end{array}$ & $\begin{array}{l}\mathbf{5} \\
\mathbf{1} \\
\mathbf{1} \\
\mathbf{1} \\
\mathbf{2}\end{array}$ & $\begin{array}{r}13 \\
4 \\
4 \\
6 \\
9\end{array}$ \\
\hline CT & 22 & $\begin{array}{l}0-30 \\
30-60 \\
60-90 \\
90-120 \\
120-150\end{array}$ & $\begin{array}{r}10 \\
7 \\
5 \\
6 \\
6 \\
15\end{array}$ & $\begin{array}{r}69 \\
12 \\
9 \\
10 \\
12\end{array}$ & $\begin{array}{l}64 \\
36 \\
16 \\
11 \\
11 \\
11\end{array}$ & $\begin{array}{l}\mathbf{2 8} \\
\mathbf{1 0} \\
\mathbf{3 7} \\
\mathbf{2 0} \\
\mathbf{1 8}\end{array}$ & $\begin{array}{r}8 \\
2 \\
2 \\
3 \\
19\end{array}$ & $\begin{array}{r}23 \\
6 \\
5 \\
6 \\
12\end{array}$ \\
\hline MT & 22 & $\begin{array}{l}0-30 \\
30-60 \\
60-90 \\
90-120 \\
120-150\end{array}$ & $\begin{array}{r}9 \\
5 \\
5 \\
10 \\
6\end{array}$ & $\begin{array}{r}76 \\
13 \\
13 \\
10 \\
9\end{array}$ & $\begin{array}{l}92 \\
45 \\
19 \\
12 \\
11\end{array}$ & $\begin{array}{l}24 \\
15 \\
24 \\
21 \\
35\end{array}$ & $\begin{array}{r}4 \\
5 \\
12 \\
2 \\
11\end{array}$ & $\begin{array}{r}19 \\
6 \\
5 \\
7 \\
10\end{array}$ \\
\hline NT & 22 & $\begin{array}{l}0-30 \\
30-60 \\
60-90 \\
90-120 \\
120-150\end{array}$ & $\begin{array}{r}8 \\
7 \\
5 \\
5 \\
5 \\
17\end{array}$ & $\begin{array}{r}41 \\
9 \\
12 \\
16 \\
10\end{array}$ & $\begin{array}{l}56 \\
46 \\
22 \\
12 \\
11\end{array}$ & $\begin{array}{l}16 \\
11 \\
31 \\
47 \\
28\end{array}$ & $\begin{array}{l}4 \\
2 \\
1 \\
2 \\
5\end{array}$ & $\begin{array}{r}14 \\
4 \\
3 \\
5 \\
8\end{array}$ \\
\hline CT & 45 & $\begin{array}{l}0-30 \\
30-60 \\
60-90 \\
90-120 \\
120-150\end{array}$ & $\begin{array}{r}8 \\
8 \\
5 \\
8 \\
8 \\
10\end{array}$ & $\begin{array}{r}56 \\
13 \\
10 \\
9 \\
9\end{array}$ & $\begin{array}{r}105 \\
55 \\
20 \\
14 \\
16\end{array}$ & $\begin{array}{l}32 \\
27 \\
66 \\
57 \\
30\end{array}$ & $\begin{array}{r}5 \\
2 \\
3 \\
7 \\
10\end{array}$ & $\begin{array}{r}17 \\
4 \\
4 \\
6 \\
9\end{array}$ \\
\hline MT & 45 & $\begin{array}{l}0-30 \\
30-60 \\
60-90 \\
90-120 \\
120-150\end{array}$ & $\begin{array}{r}8 \\
8 \\
9 \\
9 \\
9 \\
11\end{array}$ & $\begin{array}{l}83 \\
13 \\
14 \\
11 \\
13\end{array}$ & $\begin{array}{l}66 \\
56 \\
26 \\
15 \\
12\end{array}$ & $\begin{array}{l}29 \\
35 \\
44 \\
29 \\
15\end{array}$ & $\begin{array}{r}5 \\
1 \\
2 \\
9 \\
22\end{array}$ & $\begin{array}{r}15 \\
5 \\
5 \\
7 \\
12\end{array}$ \\
\hline NT & 45 & $\begin{array}{l}0-30 \\
30-60 \\
60-90 \\
90-120 \\
120-150\end{array}$ & $\begin{array}{r}12 \\
16 \\
9 \\
13 \\
14\end{array}$ & $\begin{array}{l}57 \\
13 \\
16 \\
12 \\
10\end{array}$ & $\begin{array}{r}112 \\
52 \\
20 \\
12 \\
9\end{array}$ & $\begin{array}{l}21 \\
12 \\
29 \\
48 \\
26\end{array}$ & $\begin{array}{r}\mathbf{7} \\
\mathbf{2} \\
\mathbf{1} \\
\mathbf{3} \\
\mathbf{1 3}\end{array}$ & $\begin{array}{r}15 \\
4 \\
3 \\
5 \\
9\end{array}$ \\
\hline
\end{tabular}

$\dagger$ Significant tillage $\times \mathbf{N}$ rate $\times$ rotation cycle $\times$ soil depth interaction.

$\neq$ LSD $_{0.05}=14 \mathbf{~ k g ~ N O}_{3}-\mathrm{N} \mathrm{ha}^{-1}$ (compare tillage within $\mathbf{N}$ rate $\times$ rotation cycle $\times$ soil depth); $\mathbf{L S D}_{0.05}=14 \mathrm{~kg} \mathrm{NO}_{3}-\mathrm{N} \mathrm{ha}^{-1}$ (compare $\mathrm{N}$ rate within tillage $\times$ rotation cycle $\times$ soil depth); $\mathbf{L S D}_{0.05}=14 \mathrm{~kg} \mathrm{NO}_{3}-\mathrm{N} \mathrm{ha}^{-1}$ (compare rotation cycle within tillage $\times \mathbf{N}$ rate $\times$ soil depth); $\mathbf{L S D}_{0.05}=$ $14 \mathrm{~kg} \mathrm{NO}_{3}-\mathrm{N} \mathrm{ha}^{-1}$ (compare soil depth within tillage $\times \mathrm{N}$ rate $\times$ rotation cycle).

Soil profile $\mathrm{NO}_{3}-\mathrm{N}$ levels $(0-150 \mathrm{~cm}$ depth) in this SW-F cropping system tended to be as great as those found in the adjacent annual cropping sequence that had no fallow period but higher levels of $\mathrm{N}$ fertilizer applied (Halvorson et al., 2001). Total soil profile $\mathrm{NO}_{3}-\mathrm{N}$ levels following the dry years were high in both cropping systems. Even with no $\mathrm{N}$ fertilizer applied, total soil profile $\mathrm{N}$ reached a high of $169 \mathrm{~kg} \mathrm{NO}_{3}-\mathrm{N}$ $\mathrm{ha}^{-1}$ in Rotation Cycle 4 (Table 4) with the zero $\mathrm{N}$ rate, and a high of $241 \mathrm{~kg} \mathrm{NO}_{3}-\mathrm{N} \mathrm{ha}^{-1}$ with $45 \mathrm{~kg} \mathrm{~N}^{-1}$ applied every crop cycle, except for Rotation Cycle 4. This is comparable with the 1992 average total soil pro- file $\mathrm{NO}_{3}-\mathrm{N}$ level of $161 \mathrm{~kg} \mathrm{ha}^{-1}$ with $34 \mathrm{~kg} \mathrm{~N} \mathrm{ha}^{-1}$ applied and $352 \mathrm{~kg} \mathrm{ha}^{-1}$ with $101 \mathrm{~kg} \mathrm{~N}$ ha $^{-1}$ applied annually in the adjacent annual cropping system (Halvorson et al., 2001). This comparison demonstrates the potential to have $\mathrm{N}$ in excess of crop needs in the soil profile following dry years.

\section{SUMMARY}

The quantity of $\mathrm{N}$ removed in grain varied with tillage, $\mathrm{N}$ rate, and available moisture during the rotation cycle for this SW-F cropping system. Nitrogen fertilization generally increased the amount of $\mathrm{N}$ removed in the grain during each rotation cycle and increased the total amount of $\mathrm{N}$ removed in the grain with six SW crops. Only 21 and $17 \%$ of the $\mathrm{N}$ applied as fertilizer was removed in the grain for the 22 and $45 \mathrm{~kg} \mathrm{ha}^{-1} \mathrm{~N}$ rates, respectively, by six SW crops. These low $\mathrm{N}$ use efficiencies indicate that more $\mathrm{N}$ was being applied than was being removed by the crop, thus contributing to excess residual $\mathrm{NO}_{3}-\mathrm{N}$ in the soil profile. Grain $\mathrm{N}$ concentration increased with increasing $\mathrm{N}$ rate, but varied with tillage system. Grain N concentrations for the fertilized treatments were higher with CT than with NT.

Soil $\mathrm{NO}_{3}-\mathrm{N}$ levels did not show signs of accumulating in the soil profile with respect to $\mathrm{N}$ fertilization or tillage treatments prior to the dry crop seasons. During and following the dry crop cycles, postharvest soil $\mathrm{NO}_{3}-\mathrm{N}$ levels increased with increasing $\mathrm{N}$ rate and tended to be greater with CT and MT than with NT. The data indicate that even with no $\mathrm{N}$ fertilizer applied, soil $\mathrm{NO}_{3}-\mathrm{N}$ levels increased in the soil profile during the dry crop cycles. During the wetter rotation cycles, some $\mathrm{NO}_{3}-\mathrm{N}$ may have moved below the root zone of $\mathrm{SW}$, as evidenced by a low level of postharvest soil $\mathrm{NO}_{3}-\mathrm{N}$ in the profile, which cannot be accounted for by grain $\mathrm{N}$ removal. This would be consistent with the observations reported by Campbell et al. (1975) and Campbell et al. (1984) for cultivated systems in semiarid areas of Canada.

The results show that in a SW-F system, grain $\mathrm{N}$ and residual soil $\mathrm{NO}_{3}-\mathrm{N}$ responses to $\mathrm{N}$ fertilization and tillage system will vary with cropping season and climatic conditions. Following dry years, where $\mathrm{N}$ use is low, reducing $\mathrm{N}$ fertilizer applications rates may be necessary to reduce the level of $\mathrm{NO}_{3}-\mathrm{N}$ in the root zone and reduce the potential for ground water contamination. Soil testing for residual $\mathrm{NO}_{3}-\mathrm{N}$ is essential for efficient $\mathrm{N}$ management within tillage and cropping systems.

\section{ACKNOWLEDGMENTS}

The authors acknowledge the contribution of the Area IV Soil Conservation Districts in North Dakota for providing the land and assisting with financial resources to conduct this longterm study; the assistance of Dr. Gary Richardson, USDAARS Statistician, Fort Collins, CO, with the statistical analyses; and the assistance of F. Jacober, J. Harms, L. Renner, M. Hatzenbuhler, and G. Brucker in conducting the study and collecting the field and laboratory data. 


\section{REFERENCES}

Aase, J.K., and G.M. Schaefer. 1996. Economics of tillage practices and spring wheat and barley crop sequence in the northern Great Plains. J. Soil Water Conserv. 51:167-170.

Black, A.L., and A. Bauer. 1990. Strategies for storing and conserving soil water in the northern Great Plains. p. 137-139. In P.W. Unger et al. (ed.) Proc. International Conference on Dryland Farming, Bushland, TX. 15-19 Aug. 1988. Texas Agric. Exp. Stn., College Station, TX.

Black, A.L., P.L. Brown, A.D. Halvorson, and F.H. Siddoway. 1981. Dryland cropping strategies for efficient water-use to control saline seeps in the northern Great Plains, U.S.A. Agric. Water Manage. 4:295-311.

Black, A.L., and D.L. Tanaka. 1997. A conservation tillage-cropping systems study in the Northern Great Plains of the United States. p. 335-342. In E.A. Paul et al. (ed.) Soil organic matter in temperate agroecosystems-Long-term experiments in North America. CRC Press, Boca Raton, FL.

Campbell, C.A., R. De Jong, and R.P. Zentner. 1984. Effect of cropping, summerfallow and fertilizer nitrogen on nitrate-nitrogen lost by leaching on a brown chernozemic loam. Can. J. Soil Sci. 64:61-74.

Campbell, C.A., W. Nicholaichuk, and F.G. Warder. 1975. Effects of wheat-summer-fallow rotation on subsoil nitrate. Can. J. Soil Sci. 55:279-286

Campbell, C.A., R.P. Zentner, F. Selles, and O.O. Akinremi. 1993. Nitrate leaching as influenced by fertilization in the brown soil zone. Can. J. Soil Sci. 73:387-397.

Deibert, E.J., E. French, and B. Hoag. 1986. Water storage and use by spring wheat under conventional tillage and no-till in continuous and alternate crop-fallow systems in the northern Great Plains. J. Soil Water Conserv. 41:53-58.

Grant, C.A., and G.P. Lafond. 1994. The effects of tillage systems and crop rotations on soil chemical properties of a black chernozemic soil. Can. J. Soil Sci. 74:301-306.

Halvorson, A.D. 1990. Management of dryland saline seeps. p. 372 392. In K.K. Tanji (ed.) Agricultural salinity assessment and management. ASCE Manuals and Reports on Engineering Practice No. 71. Am. Soc. Civil Eng., New York.

Halvorson, A.D., and A.L. Black. 1974. Saline-seep development in dryland soils of northeastern Montana. J. Soil Water Conserv. 29: $77-81$.

Halvorson, A.D., and A.L. Black. 1985. Safflower helps recover residual nitrogen fertilizer. Montana AgResearch 2:19-22.
Halvorson, A.D., A.L. Black, J.M. Krupinsky, S.D. Merrill, B.J. Wienhold, and D.L. Tanaka. 2000. Spring wheat response to tillage and N fertilization within a crop-fallow system. Agron. J. 92:288-294.

Halvorson, A.D., B.J. Wienhold, and A.L. Black. 2001. Tillage and nitrogen fertilization influence grain and soil nitrogen in an annual cropping system. Agron. J. 93:836-841.

Izaurralde, R.C., Y. Feng, J.A. Robertson, W.B. McGill, N.G. Juma, and B.M. Olson. 1995. Long-term influence of cropping systems, tillage methods, and $\mathrm{N}$ sources on nitrate leaching. Can. J. Soil Sci. 75:497-505.

Lachat Instruments. 1989. Nitrate in $2 \mathrm{M} \mathrm{KCl}$ soil extracts. QuikChem Method No. 12-107-04-1-B. Lachat Instruments, Milwaukee, WI.

Lachat Instruments. 1992. Total Kjeldahl nitrogen in soil/plant. QuikChem Method No. 13-107-06-2-D. Lachat Instruments, Milwaukee, WI.

Peterson, G.A., A.J. Schlegel, D.L. Tanaka, and O.R. Jones. 1996 Precipitation use efficiency as affected by cropping and tillage systems. J. Prod. Agric. 9:180-186.

SAS Institute. 1991. SAS/STAT users guide. Version 6. 4th ed. SAS Inst., Cary, NC.

Schepers, J.S., D.D. Francis, and M.T. Thompson. 1989. Simultaneous determination of total $\mathrm{C}$, total $\mathrm{N}$, and ${ }^{15} \mathrm{~N}$ on soil and plant material. Commun. Soil Sci. Plant Anal. 20:949-959.

Stewart, B.A. 1990. Dryland farming: The North American experience. p. 54-59. In P.W. Unger et al. (ed.) Proc. International Conference on Dryland Farming, Bushland, Texas. 15-19 Aug. 1988. Texas Agric. Exp. Stn., College Station, TX.

Tanaka, D.L. 1985. Chemical and stubble-mulch fallow influences on seasonal soil water contents. Soil Sci. Soc. Am. J. 49:728-733.

Tanaka, D.L. 1989. Spring wheat plant parameters as affected by fallow methods in the northern Great Plains. Soil Sci. Soc. Am. J. 53:1506-1511.

Tanaka, D.L., and R.L. Anderson. 1997. Soil water storage and precipitation storage efficiency of conservation tillage systems. J. Soil Water Conserv. 52:363-367.

Technicon Industrial Systems. 1973. Nitrate and nitrite in water and wastewater. Industrial method no. 100-70W. Technicon Industrial Systems, Tarrytown, NY.

Wienhold, B.J., and A.D. Halvorson. 1998. Cropping systems influences on several soil quality attributes in the Northern Great Plains. J. Soil Water Cons. 53:254-258.

Wienhold, B.J., and A.D. Halvorson. 1999. N-mineralization responses to cropping, tillage, and $\mathrm{N}$ rate in the Northern Great Plains. Soil Sci. Soc. Am. J. 63:192-196. 